\title{
Mystery Case: An infant with developmental delay, epileptic spasms, and acrocyanosis
}

Priyanka Madaan, DM, Lokesh Saini, DM, Sameer Vyas, DM, Savita Verma Attri, MD, and Jitendra Kumar Sahu, DM

Neurology ${ }^{\circledR}$ 2020;94:939-942. doi:10.1212/WNL.0000000000009479

\section{Correspondence}

Dr. Sahu

jsh2003@gmail.com

Figure 1 Skin findings in the index patient
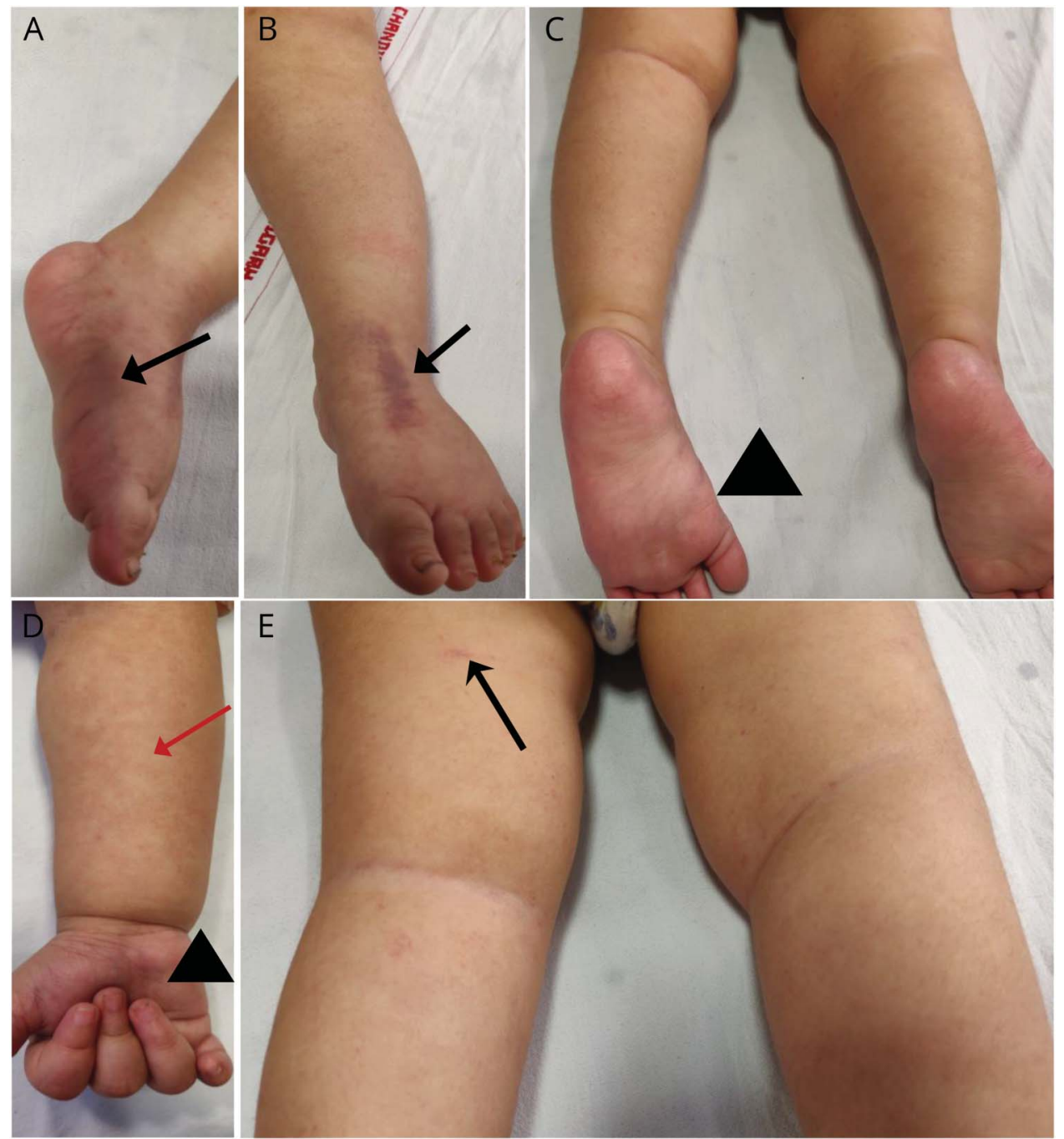

Note the spontaneous ecchymosis (black arrows; A, B, E), acrocyanosis (arrowheads; C, D), and mottled appearance of the forearm (red arrow; D).

A 10-month-old girl presented with global developmental delay, epileptic spasms, and easy bruisability. She was fourth-born of third-degree consanguineous parents with 3 healthy siblings. The perinatal period was uneventful. Examination revealed microcephaly, central

From the Pediatric Neurology Unit (P.M., L.S., J.K.S.) and Department of Pediatrics (S.V.A.), Advanced Pediatrics Centre, and Department of Radiodiagnosis and Imaging, Section of Neuroimaging and Interventional Radiology (S.V.), Postgraduate Institute of Medical Education and Research, Chandigarh; and Council of Scientific and Industrial Research (P.M.), New Delhi, India. Go to Neurology.org/N for full disclosures. Funding information and disclosures deemed relevant by the authors, if any, are provided at the end of the article. 


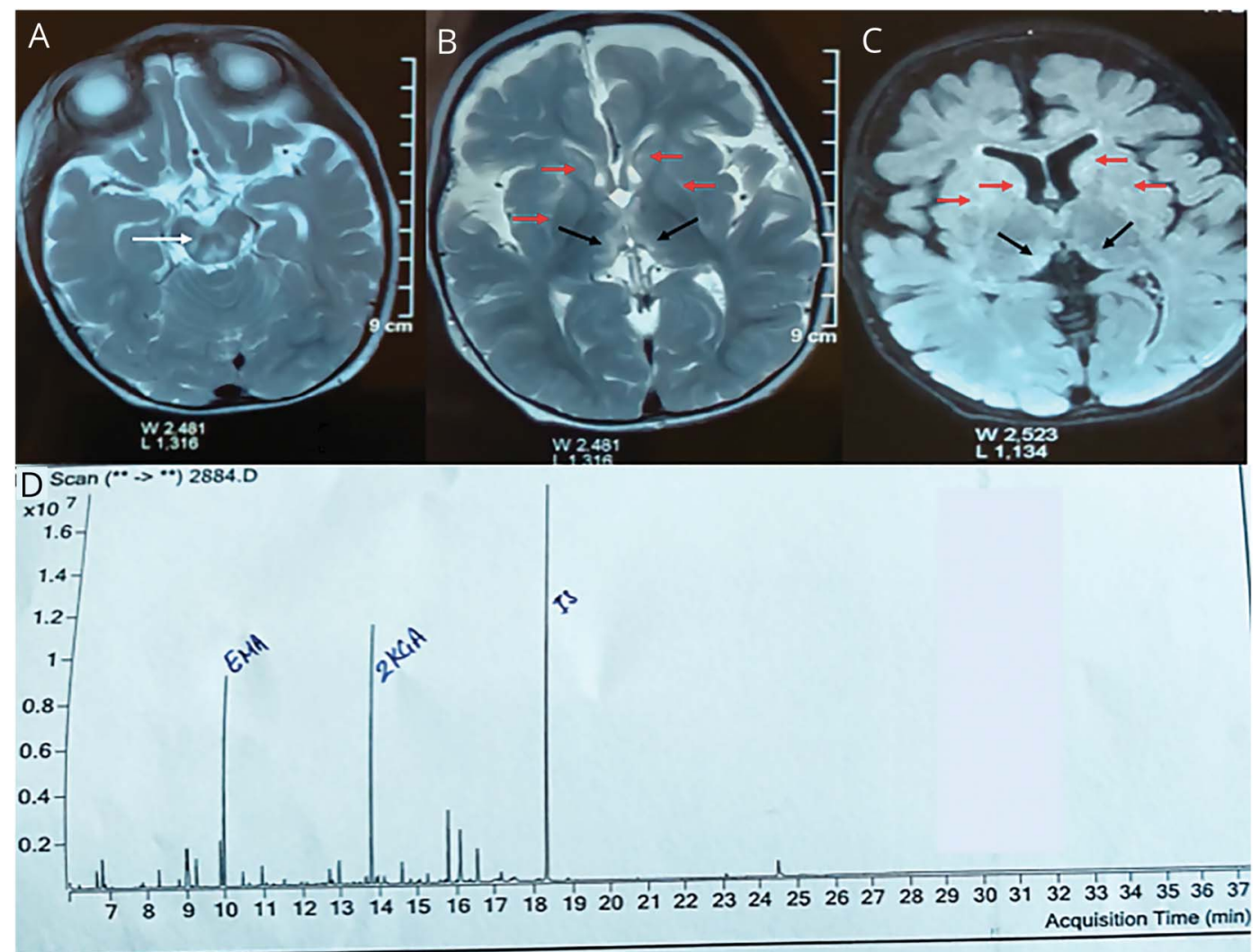

T2-weighted (A, B) and T2 fluid-attenuated inversion recovery (C) axial images show hyperintensities in midbrain (tegmentum; white arrow), bilateral caudate, putamen (red arrows), and thalamic pulvinar region (black arrows).Total ion chromatogram (D) of urine metabolites by GCMS shows increased excretion of ethylmalonic acid (EMA), 2-ketoglutaric acid (2-KGA), isobutrylglycine, and isovalerylglycine.

hypotonia, acrocyanosis, mottled skin, and petechiae over extremities (figure 1). Neuroimaging revealed peculiar findings (figure 2). EEG revealed modified hypsarrhythmia (figure 3). Epileptic spasms resolved with oral prednisolone therapy (given at $3 \mathrm{mg} / \mathrm{kg} / \mathrm{d}$ for 2 weeks followed by tapering over 6 weeks). She had elevated $\mathrm{C}_{4}$-acylcarnitines on tandem mass spectrometry (TMS) and urinary ethylmalonic acid on urine gas chromatography mass spectrometry (GCMS). The diagnosis of ethylmalonic encephalopathy (EE) was confirmed genetically (c.487C > T; p.Arg163Trp homozygous variation in ETHE1). She was initiated on $\mathrm{N}$-acetyl cysteine, metronidazole, and mitochondrial cocktail but died of an acute crisis at 14 months of age.

\section{Discussion}

EE is a rare infantile-onset metabolic encephalopathy with an abysmal prognosis. ${ }^{1}$ It is characterized by chronic diarrhea, recurrent petechiae, acrocyanosis, developmental delay or regression, and an unusual metabolic signature in plasma and urine. ETHE1 codes for mitochondrial sulfur dioxygenase, abnormalities that lead to accumulation of hydrogen sulfide $\left(\mathrm{H}_{2} \mathrm{~S}\right)$ in gut and tissues. ${ }^{1,2}$ Accumulated sulfides subsequently inhibit several enzymes such as short-chain acyl-CoA dehydrogenase (SCAD) or cytochrome oxidase, resulting in vasotoxic and neurologic effects. ${ }^{1-3}$

Other manifestations of EE include epilepsy, sensory neuropathy, and crescentic glomerulonephritis. ${ }^{4}$ Epileptic spasms have also been reported in the literature and are usually refractory to adrenocorticotropin, vigabatrin, and steroids. ${ }^{4}$ The index child, however, responded to steroids. Although the mechanism of action of oral steroids in epileptic spasms is unclear, the inhibition of corticotropin-releasing hormone overexpression may be responsible.

TMS and GCMS are widely used screening investigations for various inborn errors of metabolism, including EE. They are based on the principles of mass spectrometry (for identification and quantification of metabolites based on mass to charge ratio) and gas chromatography (for separation of various metabolites based on their volatility). The metabolic abnormalities in EE include lactic acidemia, elevated plasma $\mathrm{C}_{4}$ and $\mathrm{C}_{5}$ acyl-carnitines, and ethylmalonic aciduria. A similar metabolic profile may also be seen in SCAD deficiency, Jamaican vomiting sickness, and glutaric 


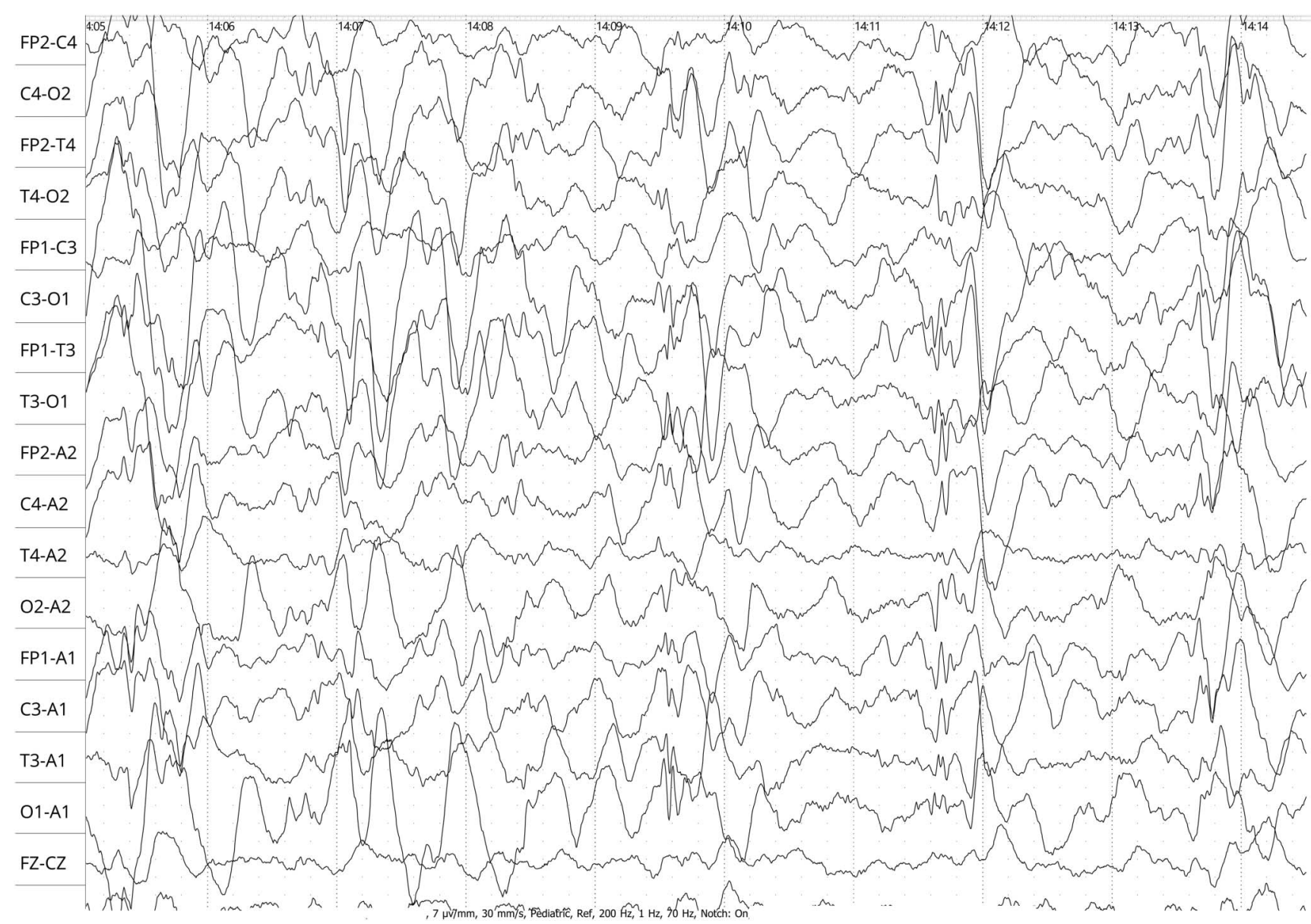

Ten-second EEG epoch (pediatric montage; sensitivity $70 \mu \mathrm{V}$; sweep speed $30 \mathrm{~mm} / \mathrm{s}$ ) shows bursts of polyspike wave discharges followed by attenuation and posterior-dominant high-amplitude slow waves, which is consistent with modified hypsarrhythmia.

acidemia type 2 but classical clinical phenotype in EE may provide a diagnostic clue. ${ }^{1}$

Treatment aims at reducing $\mathrm{H}_{2} \mathrm{~S}$ accumulation. Metronidazole and $\mathrm{N}$-acetyl cysteine are thought to be useful. ${ }^{4}$ Besides this, orthotopic liver transplantation corrects the metabolic defect and improves psychomotor outcomes. ${ }^{5,6}$ Thus early recognition and referral to liver transplant centers may significantly improve outcomes.

\section{Acknowledgment}

The authors thank the parents of the patient for images and adding to the literature.

\section{Study funding}

No targeted funding reported. The patient was a part of project supported by the Council of Scientific and Industrial Research, New Delhi.

\section{Disclosure}

The authors report no relevant disclosures. Go to Neurology. org/ $\mathrm{N}$ for full disclosures.
Appendix Authors

\begin{tabular}{lll}
\hline Name & Location & Contribution \\
\hline $\begin{array}{l}\text { Priyanka } \\
\text { Madaan, } \\
\text { DM }\end{array}$ & $\begin{array}{l}\text { Postgraduate Institute of } \\
\text { Medical Education and } \\
\text { Research, Chandigarh; CSIR, } \\
\text { New Delhi, India }\end{array}$ & $\begin{array}{l}\text { Patient management, } \\
\text { literature review, initial draft } \\
\text { manuscript, preparation } \\
\text { and final approval of the } \\
\text { version to be published }\end{array}$ \\
\hline $\begin{array}{l}\text { Lokesh } \\
\text { Saini, DM }\end{array}$ & $\begin{array}{l}\text { Postgraduate Institute of } \\
\text { Medical Education and } \\
\text { Research, Chandigarh, India }\end{array}$ & $\begin{array}{l}\text { Patient management, } \\
\text { critical review of the } \\
\text { manuscript, final approval } \\
\text { of the version to be } \\
\text { published }\end{array}$ \\
\hline $\begin{array}{l}\text { Sameer } \\
\text { Vyas, DM }\end{array}$ & $\begin{array}{l}\text { Postgraduate Institute of } \\
\text { Medical Education and } \\
\text { Research, Chandigarh, India }\end{array}$ & $\begin{array}{l}\text { Analysis of the radiologic } \\
\text { data, critical review of } \\
\text { manuscript, final approval } \\
\text { of the version to be } \\
\text { published }\end{array}$ \\
\hline $\begin{array}{l}\text { Savita } \\
\text { Verma } \\
\text { Attri, MD }\end{array}$ & $\begin{array}{l}\text { Postgraduate Institute of } \\
\text { Medical Education and } \\
\text { Research, Chandigarh, India }\end{array}$ & $\begin{array}{l}\text { Analysis of metabolic tests, } \\
\text { critical review of } \\
\text { manuscript, final approval } \\
\text { of the version to be } \\
\text { published }\end{array}$ \\
\hline
\end{tabular}

Continued 
Appendix (continued)

\begin{tabular}{lll}
\hline Name & Location & Contribution \\
\hline $\begin{array}{ll}\text { Jitendra } \\
\text { Kumar }\end{array}$ & $\begin{array}{l}\text { Postgraduate Institute of } \\
\text { Sahu, DM }\end{array}$ & $\begin{array}{l}\text { Patient management, } \\
\text { critical review of manuscript }\end{array}$ \\
& Research, Chandigarh, India & $\begin{array}{l}\text { for important intellectual } \\
\text { content, final approval } \\
\text { of the version to be } \\
\text { published }\end{array}$ \\
\end{tabular}

\section{References}

1. Tiranti V, D'Adamo P, Briem E, et al. Ethylmalonic encephalopathy is caused by mutations in ETHE1, a gene encoding a mitochondrial matrix protein. Am J Hum Genet 2004;74:239-252

2. Tiranti V, Viscomi C, Hildebrandt T, et al. Loss of ETHE1, a mitochondrial dioxygenase, causes fatal sulfide toxicity in ethylmalonic encephalopathy. Nat Med 2009; 15:200-205.

3. Di Meo I, Fagiolari G, Prelle A, et al. Chronic exposure to sulfide causes accelerated degradation of cytochrome $\mathrm{C}$ oxidase in ethylmalonic encephalopathy. Antioxid Redox Signal 2011;15:353-362.

4. Papetti L, Garone G, Schettini L, et al. Severe early onset ethylmalonic encephalopathy with West syndrome. Metab Brain Dis 2015;30:1537-1545.

5. Dionisi-Vici C, Diodato D, Torre G, et al. Liver transplant in ethylmalonic encephalopathy: a new treatment for an otherwise fatal disease. Brain 2016;139:1045-5.

6. Tam A, Al Dhaheri NS, Mysore K, et al. Improved clinical outcome following liver transplant in patients with ethylmalonic encephalopathy. Am J Med Genet A 2019;179: 1015-1019.

\section{Mystery Case responses}

The Mystery Case series was initiated by the Neurology ${ }^{\circledR}$ Resident \& Fellow Section to develop the clinical reasoning skills of trainees. Residency programs, medical student preceptors, and individuals were invited to use this Mystery Case as an educational tool. Responses to multiple choice questions formulated using this case were solicited through a group email sent to the American Academy of Neurology Consortium of Neurology Residents and Fellows and through social media. We received 123 responses. The majority of respondents (77\%) had been in practice for $1-4$ years; $58 \%$ were residents or fellows, while $26 \%$ were faculty/board-certified physicians; the remainder were medical students or advanced practice providers. Fifty-eight percent resided outside the United States. A wide range of practice settings was represented.

The 10-month-old patient, born of consanguineous parents, presented with global developmental delay, epileptic spasms, and easy bruising. She was found to have microcephaly, central hypotonia, acrocyanosis, mottled skin, and limb petechiae on examination and an EEG revealed hypsarrhythmia. Hypsarrhythmia is a disorganized pattern of high-amplitude asynchronous slow waves, multifocal spikes, and polyspikes, ${ }^{1}$ suggestive of significant cortical dysfunction. The triad of hypsarrhythmia, epileptic spasms, and developmental impairment is called West syndrome. Most respondents correctly identified rhythmically repetitive spikes (70\%), paroxysmal generalized $4-\mathrm{Hz}$ to $6-\mathrm{Hz}$ polyspike and wave discharges (63\%), and low voltage, fast waves and spikes originating from the same cortical area $(72 \%)$ as not being features of hypsarrhythmia.
Microcephaly is defined as an occipitofrontal circumference of more than 2 SD below the mean. Primary microcephaly is caused by a fetal brain insult leading to an impairment of neurogenesis and most severely affects the forebrain (correctly noted by $39 \%$ of responses). Genetic disorders (including monogenic disorders, genetic syndromes, and chromosomal abnormalities) and prenatal brain injury (such as teratogenic exposure) account for just under a third of primary cases each and nearly $50 \%$ are underdetermined. ${ }^{2}$ Secondary microcephaly occurs when an insult to a previously normal brain causes a reduction in dendritic processes and synaptic connections (e.g., postnatal TORCH [toxoplasmosis, other (syphilis, varicellazoster, parvovirus B19), rubella, cytomegalovirus, and herpes] infections, hypoxic-ischemic insults, or severe malnutrition). Metabolic disorders can also be associated with microcephaly but the coexistence is low $\left(\sim 1-5 \%^{3}\right)$.

The final diagnosis was EE, correctly made by $67 \%$ of respondents. SCAD deficiency and glutaric academia type 2 share the same metabolic profile (lactic acidemia, elevated plasma $\mathrm{C}_{4}$ and $\mathrm{C}_{5}$ acyl-carnitines, and ethylmalonic aciduria) and were therefore the most appropriate differential diagnoses, chosen by $62 \%$ and $50 \%$ of respondents, respectively.

Metabolic disorders are characterized by the deficiency or dysfunction of essential metabolites and cause neurologic symptoms due to impaired brain development or functioning. Although a child with a metabolic disorder typically presents with global neurodevelopmental delay and accumulating disability, acute encephalopathy, ataxia, childhood epilepsy, or movement disorders are increasingly recognized presentations. Only one respondent correctly answered all questions; this highlights how such cases are considered challenging. However, having a structured approach focusing on the presenting age, developmental progression, and peculiar examination findings and obtaining a basic metabolic screen and neuroimaging should significantly narrow the differential diagnosis and ease discussions with specialists.

\section{Robert Hurford, MSc, MRCP (UK)}

Nuffield Department of Clinical Neurosciences, University of Oxford, UK

\section{References}

1. Wirrell E. Infantile, childhood, and adolescent epilepsies. Continuum 2016;22:60-93.

2. Von der Hagen M, Pivarcsi M, Liebe J, et al. Diagnostic approach to microcephaly in childhood: a two-center study and review of the literature. Dev Med Child Neurol 2014;56:732.

3. Ashwal S, Michelson D, Plawner L, et al. Practice parameter: evaluation of the child with microcephaly (an evidence-based review): report of the quality standards subcommittee of the American Academy of Neurology and the practice committee of the Child Neurology Society. Neurology 2009;73:887. 


\section{Neurology}

\section{Mystery Case: An infant with developmental delay, epileptic spasms, and acrocyanosis}

Priyanka Madaan, Lokesh Saini, Sameer Vyas, et al.

Neurology 2020;94;939-942 Published Online before print May 4, 2020

DOI 10.1212/WNL.0000000000009479

\section{This information is current as of May 4, 2020}

\section{Updated Information \& Services}

References

Subspecialty Collections

Permissions \& Licensing

Reprints including high resolution figures, can be found at: http://n.neurology.org/content/94/21/939.full

This article cites 9 articles, 1 of which you can access for free at: http://n.neurology.org/content/94/21/939.full\#ref-list-1

This article, along with others on similar topics, appears in the following collection(s):

All Genetics

http://n.neurology.org/cgi/collection/all_genetics

All Pediatric

http://n.neurology.org/cgi/collection/all_pediatric

Infantile spasms

http://n.neurology.org/cgi/collection/infantile_spasms

Metabolic disease (inherited)

http://n.neurology.org/cgi/collection/metabolic_disease_inherited

MRI

http://n.neurology.org/cgi/collection/mri

Information about reproducing this article in parts (figures,tables) or in its entirety can be found online at:

http://www.neurology.org/about/about_the_journal\#permissions

Information about ordering reprints can be found online:

http://n.neurology.org/subscribers/advertise

Neurology ${ }^{\circledR}$ is the official journal of the American Academy of Neurology. Published continuously since 1951, it is now a weekly with 48 issues per year. Copyright @ 2020 American Academy of Neurology. All rights reserved. Print ISSN: 0028-3878. Online ISSN: 1526-632X.

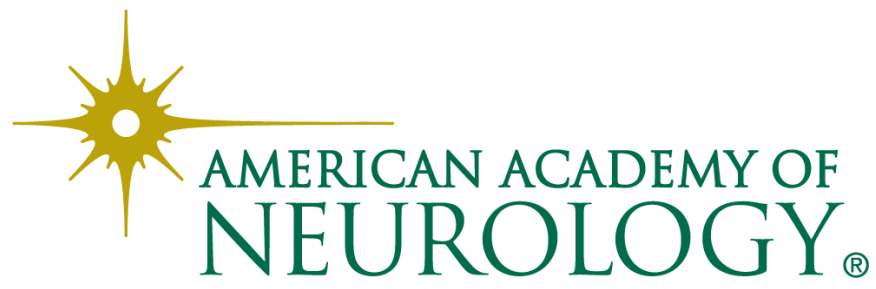

